\title{
Pengenalan Wajah Secara Real-Time Menggunakan Algoritma LBPH Pada Raspiberry PI
}

\author{
Hermansyah Alam, Khairul Saleh, Khairina Juliana BR.Pane \\ Program Studi Teknik Informatika, Fakultas Teknologi Industri \\ Institut Teknologi Medan (ITM) \\ Jl. Gedung Arca No. 52 Medan Telp. (061) 7363771 Kode pos 20217 \\ e-mail: herman_itm@yahoo.co.id
}

\begin{abstract}
Abstrak - Perkembangan manusia dan teknologi dalam kehidupan tidak dapat dipisahkan.Sebagian besar kegiatan yang dilakukan oleh manusia saat ini tergantung pada teknologi.Keamanan juga menjadi isu penting dalam kehidupan manusia. Manusia membutuhkan keamanan untuk memantau area yang dianggap perlu, seperti rumah, kantor, atau tempat lain yang dirahasiakan. Perkembangan dunia nirkabel semakin dibutuhkan karena kebutuhan yang sangat dinamis yang tidak dibatasi oleh ruang dan waktu.Aplikasi teknologi nirkabel semakin banyak digunakan dalam banyak hal seperti di industri dan sektor komunikasi.Tujuan dari proyek ini adalah untuk membangun robot pengintai yang dapat digunakan untuk memvisualisasikan gambar yang ditangkap di tempat dan mengenalinya.pengenalan wajah secara real-time menggunakan Raspberry Pi dan Webcam yang dapat diletakan pada suatu area yang memiliki fungsi sama seperti CCTV tetapi memiliki kemampuan untuk mengenali wajah orang yang ada di area tersebut serta pemantauannya dapat di lakuakan dari jarak jauh melalui bantuan dari internet dengan konsep IOT. Sehinga dapat memudahkan manusia dalam memonitoring suatu area seperti mengawasi orang lanjut usia ataupun untuk mengawasi anak-anak yang ada di rumah dari jarak jauh melalui teknologi Wi-Fi.
\end{abstract}

Kata kunci : CCTV, IOT, Raspberry Pi, Wi-Fi.

\begin{abstract}
The development of humans and technology in life cannot be separated. Most of the activities carried out by humans today depend on technology. Security is also an important issue in human life. Humans need security to monitor areas deemed necessary, such as homes, offices, or other places withheld. The development of the wireless world is increasingly needed because of the very dynamic needs that are not limited by time and space. The application of wireless technology is increasingly being used in many ways such as in the industry and communications sector. The aim of this project is to build surveillance robots that can be used to visualize images that are captured on the spot and recognize it. face recognition in real time using Raspberry Pi and webcams that can be placed in an area that has the same function as CCTV but has the ability to recognize the faces of people in the area and monitoring can be done remotely through help from the internet with the concept of IoT. So that it can be easier for humans to monitor an area such as watching over the elderly or to supervise children at home remotely through Wi-Fi technology.
\end{abstract}

Keywords : $\quad$ CCTV, IoT, Raspberry Pi, Wi-Fi.

\section{PENDAHULUAN}

Dalam masyarakat saat ini, pengembangan kebutuhan hidup dan teknologi tidak dapat dipisahkan. Salah satu indikasi bahwa perkembangan dunia semakin meningkat dapat dilihat seiring dengan perkembangan teknologi(Pane et al. 2018). Komunikasi adalah bagian dari perkembangan teknologi termasuk bagian yang mendukung untuk menciptakan kemudahan yang memanfaatkan teknologi yang ada.Jaringan komputer adalah salah satu alat untuk menyampaikan informasi yang dapat digunakan untuk berkomunikasi antara alat-alat teknologi. Banyak alat komunikasi yang muncul dapat dihubungkan dengan kabel atau tanpa kabel(Lu et al. 2013). Perkembangan dunia nirkabel semakin dibutuhkan karena kebutuhan yang sangat dinamis yang tidak dibatasi oleh ruang dan waktu.Aplikasi teknologi nirkabel semakin banyak digunakan dalam banyak hal seperti di industri dan sektor komunikasi.

Dengan memanfaatkan perkembangan teknologi seluler yang ada, diharapkan kontrol alat yang digunakan dapat lebih efisien karena tidak ada batasan jarak antara pengontrol dengan alat yang akan dikontrol (Madkar et al. 2016). Wireless Fidelity (WiFi) adalah salah satu jenis komunikasi nirkabel jarak pendek yang digunakan di kantor dan rumah yang dapat mengirimkan data dalam bentuk teks, suara, dan gambar(Lu et al. 2013).

Internet of things (IOT) sebagai perpanjangan dari Internet adalah konsep jaringan yang menggunakan jaringan internet dengan tujuan memperluas manfaat dari konektivitas internet yang tersambung secara terus-menerus sesuai dengan beberapa tujuan seperti mewujudkan identifikasi, lokasi, pelacakan, pemantauan, berbagi data, remote control, dan 
berbagai hal. Saat ini, dengan perkembangan teknologi IOT semakin banyak objek fisik biasa dapat menjadi perangkat IOT dengan menanamkan atau mengintegrasikan modul komunikasi nirkabel tertentu (misalnya, Wi-Fi, Bluetooth, ZigBee, dll.)(Tao et al. 2018)

Kamera pemantau atau biasa disebut Closer Circuit Television (CCTV) pertama kali ditemukan oleh Walter Brunch. CCTV pertama kali digunakan oleh tim pelaksana peluncuran roket V- 2 pada tahun 1942 di jerman. CCTV yang diproduksi oleh perusahaan Siemens AG pada waktu itu digunakan untuk mengawasi proses peluncuran roket V-2 agar dapat diketahui apakah berfungsi dengan baik ataupun tidak. Pada saat itu, hasil dari rekaman CCTV masih sangat jelek karena resolusi nya rendah, dan belum bewarna alias masih hitam putih.

CCTV merupakan alat pengawas yang tidak mengenal Lelah dan terus menerus memantau area dimana ditempatkan, fungsi utama dari CCTV adalah dapat memonitor area tertentu ketika petugas keamanan tidak berada diarea tersebut. Pemantauan merupakan salah satu bagian dari tindakan pengamanan, pemantauan rumah dapat dilakukan dengan menggunakan jaringan internet dengan konsep IOT(Mallu 2015).

Pada penelitian ini penulis membahas pengenalan wajah secara real-time menggunakan Raspberry Pi dan Webcam yang dapat diletakan pada suatu area yang memiliki fungsi sama seperti CCTV tetapi memiliki kemampuan untuk mengenali wajah orang yang ada di area tersebut serta pemantauannya dapat di lakuakan dari jarak jauh melalui bantuan dari internet dengan konsep IOT. Sehinga dapat memudahkan manusia dalam memonitoring suatu area seperti mengawasi orang lanjut usia ataupun untuk mengawasi anak-anak yang ada di rumah.

\section{TINJAUAN PUSTAKA}

\section{Raspberry Pi}

Raspberry Pi adalah komputer single-board yang dibuat oleh Raspberry Pi Foundation, sebuah badan amal yang dibentuk dengan tujuan utama memperkenalkan kembali keterampilan komputer tingkat rendah untuk anak-anak di Inggris. Tujuannya adalah untuk menghidupkan kembali revolusi microcomputer dari tahun 1980-an, yang menghasilkan satu generasi programmer terampil[8].

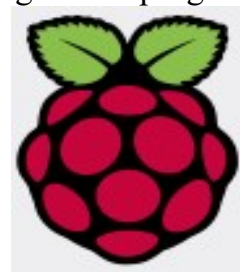

Gambar 1 Logo Raspberry Pi (https://www.raspberrypi.org)

\section{Nama Raspberry Pi}

Nama Raspberry ini terinspirasi dari vendorvendor terkenal yang menggunakan nama buahbuahan (seperti Apple, BlackBerry, dan Apricot). Nama Pi merupakan kepanjangan dari Phyton, yaitu sebuah bahasa pemrograman interpretatif serbaguna. Pada awalnya Raspberry Pi memiliki konsep sebuah komputer sederhana yang dapat diprogram dengan Phyton.

\section{Web Camera}

Web camera (Webcam) atau yang biasa kita kenal dengan sebutan webcam, merupakan sebuah perangkat peripheral yang ada pada komputer yang berguna untuk memberikan gambaran kita secara langsung yang akan ditampilkan pada monitor komputer. Webcam adalah kamera yang gambarnya bisa di akses dengan menggunakan world wide web (www), program instant messaging, atau aplikasi komunikasi dengan tampilan video pada PC.Webcam juga digambarkan sebagai kamera video digital yang sengaja didesain sebagai kamera dengan resolusi rendah.

\section{Serial and Parallel Port Webcam}

Bisa dikatakan webcam jenis ini adalah jens webcam yang merupakan generasi awal kemunculan atau penggunaan webcam. Webcam jenis ini bisa dikatakan sudah terlalu tua dan jarang ditemukan lagi, karena sudah tidak ada yang memproduksi. Selain itu, kamera jenis ini menghasilkan kualitas gambar yang rendah dan frame rate yang rendah pula sehingga membuat orang yang menggunakannya merasa kurang puas dengan kualitas gambar yang dihasilkan oleh webcam jenis ini.

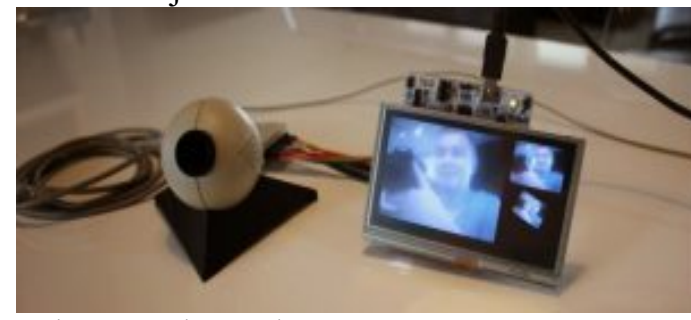

Gambar 2 Webcam dengan Serial and Parallel Port (http://www.martinrecords.com)

\section{Python}

Python adalah bahasa pemrograman interpretatif multiguna dengan filosofi perancangan yang berfokus pada tingkat keterbacaan kode. Python diklaim sebagai bahasa yang menggabungkan kapabilitas, kemampuan, dengan sintaksis kode yang sangat jelas, dan dilengkapi dengan fungsionalitas pustaka standar yang besar serta komprehensif. Python juga didukung oleh komunitas yang besar. 


\section{?2: python"}

Gambar 2.1: Logo python

(https://www.python.org/)

Salah satu fitur yang tersedia pada python adalah sebagai bahasa pemrograman dinamis yang dilengkapi dengan manajemen memori otomatis. Seperti halnya pada bahasa pemrograman dinamis lainnya, python umumnya digunakan sebagai bahasa skrip meski pada praktiknya penggunaan bahasa ini lebih luas mencakup konteks pemanfaatan yang umumnya tidak dilakukan dengan menggunakan bahasa skrip. Python dapat digunakan untuk berbagai keperluan pengembangan perangkat lunak dan dapat berjalan di berbagai platform sistem operasi.

\section{Biometrik}

Biometrik (berasal dari bahasa Yunani bios yang artinya hidup dan metron yang artinya mengukur) adalah studi tentang metode otomatis untuk mengenali manusia berdasarkan satu atau lebih bagian tubuh manusia atau kelakuan dari manusia itu sendiri.Dalam dunia teknologi informasi, biometrik relevan dengan teknologi yang digunakan utnuk menganalisa fisik dan kelakuan manusia untuk autentifikasi.Dalam dunia medis disebutkan bahwa ada berapa bagian tubuh kita yang sangat unik.Artinya, tidak dimiliki oleh lebih dari satu individu.Seperti sidik jari atau retina mata. Meskipun bentuk atau warna mata bisa saja sama, namun retina mata belum tentu sama. Begitu juga dengan suara dan struktur wajah.Bagian-bagian unik inilah yang kemudian dikembangkan sebagai atribut keamanan.

\section{METODE}

\section{Rancangan Fitur}

Adapun fitur-fitur yang dirancang dalam penelitian ini adalah sebagai berikut:

a. Pengenalan Wajah

Sistem pengenalan wajah adalah teknologi yang dapat digunakan pada gambar digital dan gambar video dari sumber video.Ada beberapa metode di mana sistem Pengenalan bekerja.Secara umum, pengenalan wajah bekerja dengan membandingkan fitur wajah yang dipilih dari gambar yang diberikan dengan wajah dalam dataset.

b. Local Binary Pattern Histograms (LBPH)

Local Binary Pattern Histogram (LBPH) adalah fitur untuk mengklasifikasi yang dikombinasikan dengan histogram dan merupakan teknik baru dari metode LBP untuk mengubah performa hasil pengenalan wajah.LBP pada umumnya didesain utuk pengenalan tekstur.LBPH adalah metode pengenalan wajah untuk diimplementasikan pada Raspiberry Pi.

\section{c. Real VNC}

Pada kamera pemantau yang memiliki kemampuan untuk face recognition menerapkan konsep IOT, yang mana dapat menggunkan jaringan Internet untuk memantau area yang sudah terpasang Raspiberry Pi dari jarak jauh melalui Smartphone/PC.

\section{Rancangan Proses}

Beberapa proses yang dirancang untuk dapat digunakan oleh pengguna dalam berinteraksi dengan aplikasi yang dirancang digambarkan dalam bentuk flowchart seperti terlihat pada Gambar 1.

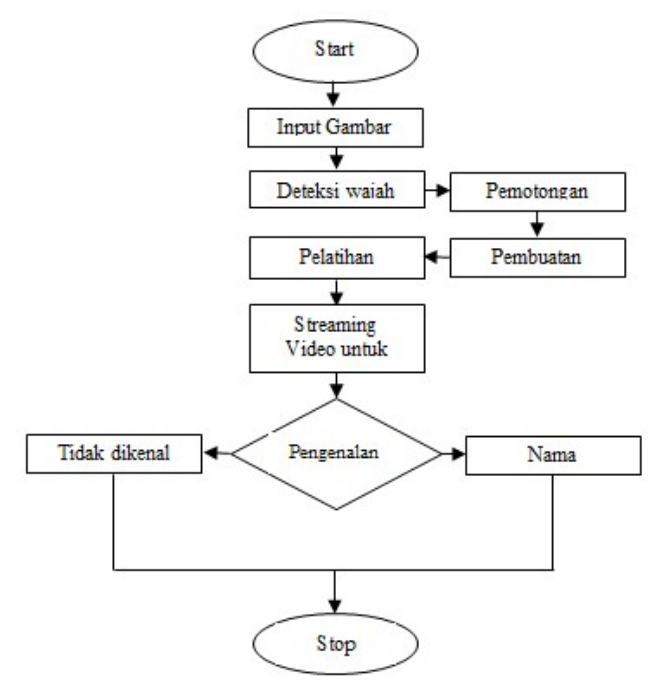

Gambar 1. Flowchart Sistem

\section{Algoritma Pengenalan Wajah}

Raspberry Pi dengan menggunkan program aplikasi python tidak bisa hanya melakukan algoritma pengenalan wajah secara langsung, tetapi membutuhkan bantuan dari algoritma pendeteksi wajah yang bertujuan untuk mengenali objek yang ada. Perkerjaan pertama bagi python untuk mengenali objek melakukan deteksi wajah dan kemudian melanjutkan dengan pengenalan wajah. Pada pengenalan wajah, kamera dari webcam dituntut untuk mengenali wajah seseorang berdasarkan database yang sudah diinput ke dalam dataset yang ada di Raspberry Pi. Database yang diinput ke dalam 
dataset Raspiberry Pi juga berupa foto atau hasil capture webcam.

\section{Deteksi Wajah}

Algoritma Haar menggunakan metode statistical dalam melakukan pendeteksian wajah. Metode ini menggunakan sample haarlike fetures. Classifier ini menggunakan gambar berukuran tetap (umumnya berukuran 24x24).

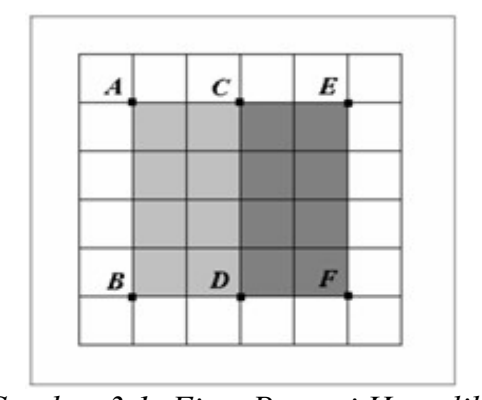

Gambar 3.1: Fitur Persegi Haar-like

Nilai Fitur $(\mathrm{ABFE})=$ Jumlah Nilai Pixel (ABDC) - Jumlah Nilai Pixel (CDFE)

Apabila NilaiFitur(ABFE) memiliki nilai di atas threshold maka dikatakan memenuhi syarat. Seperti dijelaskan pada gambar 2, apabila sebuah fitur dikatakan tidak memenuhi syarat, maka area ABFE tidak terdapat obyek yang dideteksi dan area perseginya berpindah lokasi akan tetapi jika persegi ABFE memenuhi fitur, maka aturan fitur berikutnya dilakukan. Jika semua syarat fitur dipenuhi dikatakan pada persegi ABFE dikatakan terdapat obyek.

Proses pendeteksian mobil menggunakan Haar-like feature ditunjukkan pada Gambar 5 sebagai berikut:

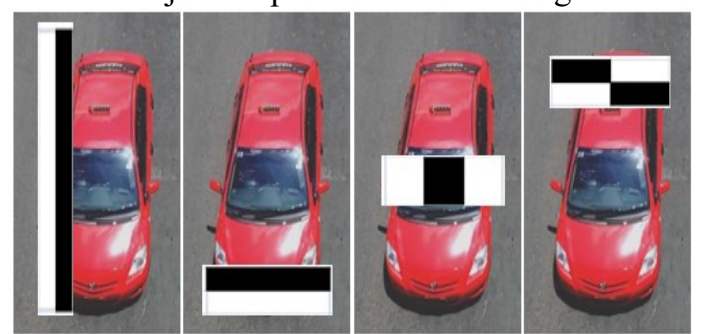

Gambar 3.2: Pendeteksian Kendaraan dengan Haarlike Feature

\section{HASIL DAN PEMBAHASAN}

Prototipe Kamera Pemantau

Raspberry Pi merupakan komputer mini dengan sistem operasi menggunakan Rasbian OS, Komputer mini ini memilki bentuk yang cukup kecil sehingga sangat mudah untuk mengaplikasikannya untuk berbagai hal, salah satunya adalah mengaplikasikannya degan webcam yang berfungsi sebagai kamera pemantau yang dapat melakukan pemantauan di area tertentu serta memilki fungsi tambahan berupa kemampuan pengenalan wajah. Gambar

merupakan Prototipe kamera pemantau menggunkan Raspberry Pi dan Webcam.

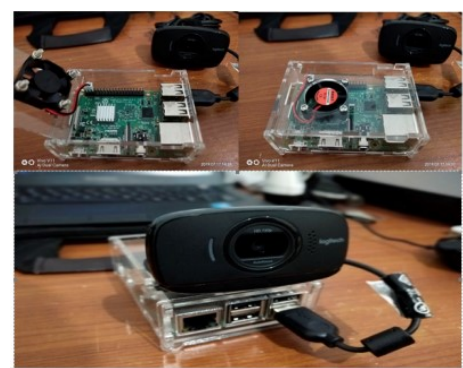

Gambar 2 Prototipe Kamera Pemantau

Pembuatan Dataset

Sebelum melakukan pengenalan wajah untuk dapat mengenali wajah seseorang, terlebih dahulu diperlukan pembuatan dataset yang akan digunakan sebagai database yang berisi kumpulan wajah dari orang-orang yang akan dikenali nantinya pada proses pengenalan wajah. Pada sistem yang dirancang ini kumpulan dari wajah-wajah orang yg akan di lakukan pengenalan wajah dibuat menggukan sistem yang secara otomatis dapat mengenali wajah dan dapat mengambil 100 contoh wajah secara cepat kemudian akan ditempatkan secara otomatis ke dalam dataset. Pada proses pengambilan 100 contoh wajah tersebut menggunkan face detector berupa Haar Cascade Clasifier dan memakan waktu kurang lebih 36.5 detik.

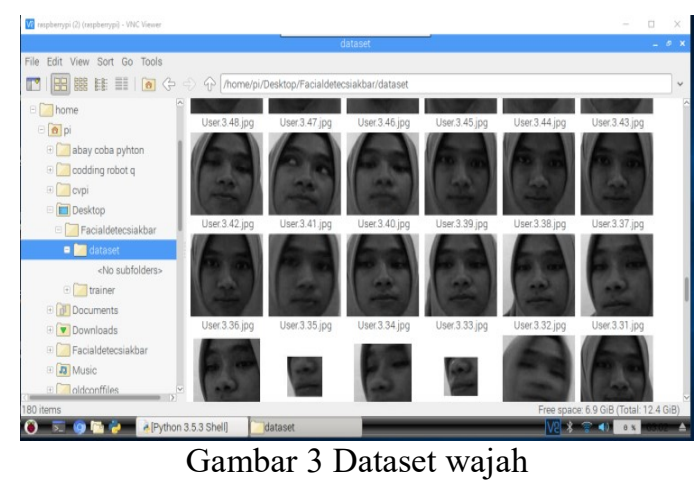

Software Pengenalan Wajah

Pada perancangan sistem ini, software yang digunakan dalam merancang kamera pemantau dengan pengenalan wajah secara real-time adalah Python dengan versi 3.5.3, software ini menggunakan library dari OpenCV untuk melakukan proses pengenalan wajah dengan menggukan algoritma LBPH. Untuk menampilkan Output dari kamera webcam pada saat pemantauan, Raspberry Pi dapat 
dilakukan dengan menggunkan Smartphone/PCyang terhubung ke internet dengan Software yang sudah terinstal sebelumnya pada Smartphone/PC dan Raspberry Pi juga terhubung ke Internet melalui WiFi. Software yang digunakan untuk melakukan Remote Dekstop dari Raspberry Pi ke Smartphone/PCadalah VNC Viewer. Gambar berikut menunjukan tampilan VNC Viewer ketika sedang menjalankan program di $P C$.

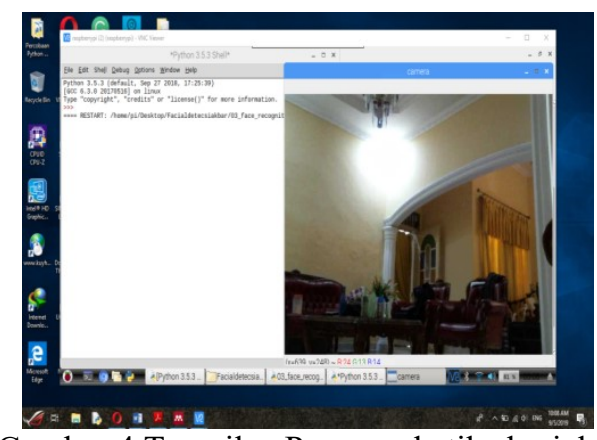

Gambar 4 Tampilan Program ketika berjalan

Analisa Kemampuan Pengenalan Wajah

Pada Proses pemantauan area, sistem dapat melakukan pemantauan diarea tersebut serta dapat melakukan pengenalan wajah. Wajah yang dapat dikenali adalah wajah yang telah terdaftar dalam dataset yang sebelumnya dibuat terlebih dahulu, dalam penelitian ini, ada dua ID yang telah terdaftar dalam dataset, pada percobaan ini ada dua wajah yang didaftarkan degab ID yang berbeda agar sistem dapat membedakan nama dari kedua waajah tersebut. Kedua wajah itu diset sebagai berikut, yaitu ID1: Akbar dan ID2: Rina. Pada Gambar berikut menunjukan uji coba yang dilakukan dalam kondisi di dalam ruangan dan sistem mampu melakukan pengenalan wajah, yang mana sistem ini dapat mengenali wajah dengan ID1 dan ID2.

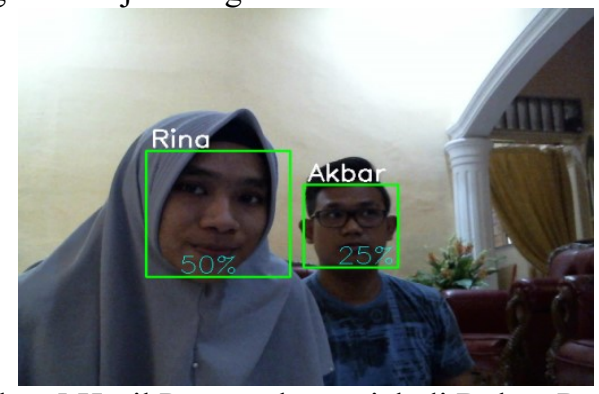

Gambar 5 Hasil Pengenalan wajah di Dalam Ruangan

Pengujian juga dilakukan di luar ruangan dengan menggunakan jarak yang lebih jauh sekitar tiga meter dengan resolusi webcam 640 x 480. Dari hasil pengujian seperti pada gambar berikut menunjukkan sistem dapat mengenali wajah dari jarak yg lebih jauh di mana sistem dapat mengenali wajah yaitu ID2 : "Rina".

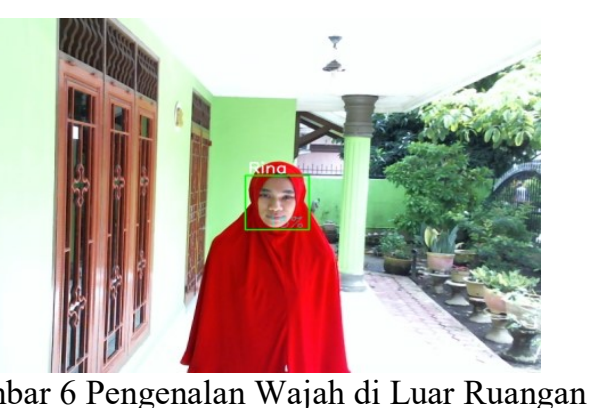

Gambar 6 Pengenalan Wajah di Luar Ruangan

Analisa Kemampuan Pemantauan Menggunakan Internet

Pada Proses pemantauan, pengguna dapat memantau keadaan di suatu area yang mana Raspberry Pi di tempatkan dari jarak jauh selama keduanya terhubung dengan jaringan internet. Pemantauan yang dilakukan dengan bantuan dari VNC Viewer yang sudah terinstal pada Smartphone/PC.Hasil pengujian menunjukan sistem dapat bekerja dengan baik untuk menggambil gambar dari jarak jauh ketika berada dari jarak yang jauh. Gambar 4.6 menampilkan gambar yang di ambil dari jarak jauh ketika Raspberry Pi berada di Universiti Malaysia Perlis kemudian Pemantauan dilakukan dari Jalan Tanjung Permai XI-A Nomor 16, Kelurahan Tanjung Gusta, Deli Serdang dan menampilkan ID1 : "Akbar" yang terdaftar sebelumnya serta menampilkan ID orang yang tidak terdaftar dengan kata "uknown".

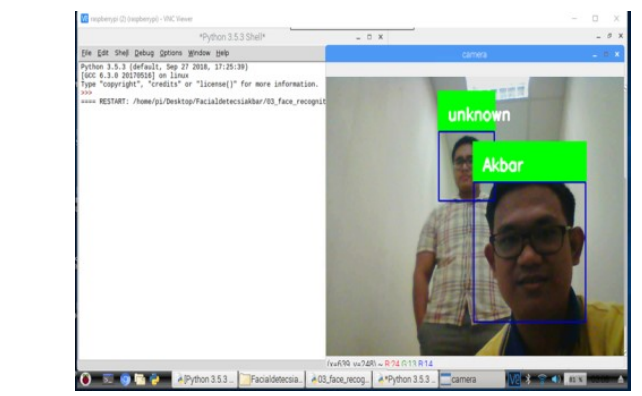

Gambar 7 Pemantauan Dari Jarak Jauh (Universiti Malaysia Perlis)

\section{KESIMPULAN}

Adapun kesimpulan dari perancangan sistem pemantau menggunakan Raspberry $\mathrm{Pi}$ ini adalah Pemantauan suatu area dengan menggunakan Internet yang berbasis IOT berhasil diterapkan dengan menggunakan Raspiberry Pi dan Webcam. Membangun Sistem Pemantauan jarak jauh menggunakan Raspberry Pi yang dikombinasikan dengan Webcam berhasil dibangun serta memiliki ukuran yang compact sehingga mudah ditempatkan dimana saja. Penerapan Algoritma LBPH pada Raspberry Pi berhasil dan dapat melakukan 
pengenalan wajah pada orang-orang yang sudah terdaftar dalam dataset yang ada pada Raspberry Pi

Ada beberapa saran yang ingin penulis berikan untuk pengembangan aplikasi ini dikemudian hari, yaitu Penggunan Raspberry Pi dan Webcam dengan kemampuan pengenalan wajah dapat dikombinasikan dengan fitur keamanan lainnya seperti pada pintu pembuka otomatis ataupun dikombinasikan dengan Surveillance Robot. Peningkatan akurasi dari proses pengenalan wajah sehingga dapat mengenali wajah dari jarak yang lebih jauh.

\section{DAFTAR PUSTAKA}

[1] Lu, Xiao, Wenjun Liu, Haixia Wang, and Qia Sun. 2013. "Robot Control Design Based on Smartphone." 2013 25th Chinese Control and Decision Conference (CCDC): 2820-23. http://ieeexplore.ieee.org/document/6561425/.

[2] Madkar, S R, Vipul Mehta, Nitin Bhuwania, and Maitri Parida. 2016. "Robot Controlled Car Using Wi-Fi Module." International Journal of Advanced Research in Computer Science and Software Engineering 6(5): 460-64.

[3] Mahmudi, Ali, and M Taufiqur Rusda. "Deteksi Senjata Tajam Dengan Metode Haar Cascade Classifier Menggunakan Teknologi SMS Gateway.” Matics (1): 27-30.
[4] Mallu, Satriawaty. 2015. "Pendeteksian Gerakan Menggunakan Internet.” I(3): 9-14.

[5] Pambudi, Wahyu Setyo et al. 2012. "Facetracker Menggunakan Metode Haar Like Feature." Jurnal Teknologi dan Informasi (TEKNOMATIKA) 2(2): 142-54.

[6] Pane, M A S, P Ehkan, K Saleh, and M Irwanto. 2018. "A Mobile Surveillance Robot Over The Wifi Network Using Atmega 8.” 20(5): 20-26.

[7] Sanjaya, W. S.Mada et al. 2018. "The Design of Face Recognition and Tracking for HumanRobot Interaction." Proceedings - 2017 2nd International Conferences on Information Technology, Information Systems and Electrical Engineering, ICITISEE 2017 2018-Janua(c): 315-20.

[8] Sheikh, Prof I Y, Ms Jaya S Vyawhare, Ms Sampada B Mahajan, and Ms Prachi R Bal. 2016. "Review Paper on Wi-Fi Surveillance Robot Using Raspberry Pi." International Journal of Research in Advent Technology (IJRAT) (April): 19-24.

[9] Tao, Ming et al. 2018. "Fast Access for ZigBeeEnabled IoT Devices Using Raspberry Pi." 2018 Chinese Control And Decision Conference (CCDC): 4281-85 